\title{
Active Learning Model in Track and Field Course for Pre-service Physical Education Teacher
}

\author{
Suroto \\ Universitas Negeri Surabaya \\ Surabaya, Indonesia \\ suroto@unesa.ac.id
}

\begin{abstract}
Active learning model in track and field course is the combination of theoretical knowledge, teaching strategy, and event officiating about track and field. This learning model is not only intended to stimulate pre-service physical education teacher to learn what or how to teach track and field, but also to give them additional skill in event organizing. So, the aim of this study is to investigate the learning effectiveness by using active learning model. The study was conducted by case study method. This study involved more than $\mathbf{1 . 7 6 0}$ students in 11 years duration. The result shows that the uniqueness activities of active learning model such like individual virtual learning, personal account of activity log, event organizer, and assisting the school in the track and field during event are able to help pre-service physical education teacher to have a deeper understanding about track and field. This approach led student to learn actively by understanding the teaching materials in the virtual learning and also taking part in the event organizing. Considering by this finding, the active learning model could be implemented and suggested in other courses or subjects.
\end{abstract}

Keywords-active learning model; track and field course; event organizing; and pre-service physical education teacher

\section{INTRODUCTION}

Running, throwing, and jumping are basic movement in every sport. Almost every student naturally can do it by them self. So that is why track and field is one of the most popular themes that can be applied in almost every school in Indonesia. It is because of those skills were performed by student, so it becomes easy to do in physical education class. Furthermore, the simple rule and equipment that is needed in track and field makes this sport doable in any condition. Track and field also has benefit for the students' health. Especially to improve their cardiorespiratory system, muscle strength, speed, agility, power and etc. However, there are some particular techniques of proper teaching strategies to help student develop their potential maximally in physical education class.

So it is important for physical education teacher to master the knowledge and skill about track and field before they teach. As the result, track and field becomes a compulsory course for pre-service physical education teacher. Understanding the knowledge of track and field is very important. Especially, connecting track and field theory in to physical education purpose. Mastering the skill of track and field is required.
Particularly, demonstrating the proper technique and give feedback of student performance. Furthermore, become skilled at teaching strategy is one of the essential key in teaching physical education.

Active Learning Model in track and field course offers preservice physical education teacher to learn theoretical knowledge, teaching strategy, and event officiating holistically. They require understanding the knowledge of track and field technique, mastering the teaching methods, and knowing the event officiating actively. As the implication of active learning, the lecture provides any kind of learning methods that can be used by pre-service physical education teacher. There are online digital resources, online personal account, independent study, teamwork learning, and officiating. So in this present paper, the aim is to analyze the effectiveness of active learning model in track and field course for pre-service physical education teacher.

Track and field is a compulsory course for pre-service physical education teacher. The course objective is to give knowledge and skill to teach track and field based on Indonesian Curriculum 2013. So there are six credits of track and field course. These credits are divided in to two sub course which are named basic track and field course and advance track and field course. Basic track and field course focuses on understanding theory and mastering skill of track and fields. On the other hand, advance track and field course converges on practicing teaching strategy and simulating officiating of track and field. However, these courses are correlating with each other. The pre-service physical education teacher has to pass basic track and field course before they take advance track and field course. In other word, basic track and field course is prepared to improve pre-service physical education teacher. But advanced track and field course is provided to applied the theory and skill in to society and students.

Active learning becomes the right choice in teaching prospective teachers to introduce the curriculum 2013. Until now, the curriculum 2013 trying to present the learning that is able to form high-order thinking with a basic classification of learning objectives consisting of four types, namely: factual (terminology and discrete facts); conceptual (categories, theories, principles, and models); procedural (knowledge of a technique, process, or methodology); and metacognitive 
(including self-assessment ability and knowledge of various learning skills and techniques) [1].

Learning by applying active learning allows teachers to increase the critical thingking competencies of learners [2]. Critical thingking is one of four competencies that must be mastered by students in order to survive and succeed in life in the $21^{\text {st }}$ century. Three other competencies, namely collaboration, communication, and creativity [3]. At the elementary and secondary education level, the Indonesian government provides advice to teachers to apply various learning models included in active learning. There are six learning models which according to Indonesian government are included in the active learning group, namely: scientific, inquiry/ discovery, cooperative, problem based learning, project based learning, and eclectic [4]. That is, the prospective teachers must know up to really master active learning strategies before they actually become required to guide the learners doing active learning.

Active learning is a learning model that involves students to inquire the knowledge deeper by them self. It gives positive effect to the student achievement [5]. Particularly to the students' behavior, cognition, and affect [6]. The utilization of active learning is also suggested to enhance students' learning competences [7]. Considering the benefit of active learning, the author has been applying this model and tries to figure out the benefit especially in track and field course.

There are five activities of active learning models in this present paper. They are online digital resources, online personal account, independent study, teamwork learning, and officiating. Online digital resources were provided for preservice physical education teacher that can be accessed anytime and anywhere. So by these online digital resources, they can select the material that they need to learn by their self. Online personal account is not only used to access the online digital resources, but also is used to measure their understanding of the teaching materials. Moreover, it can be used as selfreflection.

Independent study was given for pre-service physical education teacher to do or make some assignments. These assignments are not always in paper assignment. However, it could be a duty or responsibility to do or perform something correlating about track and field. Teamwork learning is similar with independent study, but in this activity they work together in a team. Additionally, the difficulty level is different with independent study.

The last one is officiating. Officiating is kind of track and field final project for pre-service physical education teacher. So they work collaboratively to make an event, which is track and field championship. In this event, all of them has a role and responsibility. However, they also need to know other position job and how to do that. They make these championship committees by discussion. So they committee leader announce the job description and committee member will choose their own position.

\section{METHODS}

This is a qualitative study that was conducted by case study method. The study involved totally more than $1.7602^{\text {nd }}$ semester students of physical education department in 11 years duration. Every year students work on projects in the form of athletic competitions. They act as committees in charge of planning, preparing, executing, and reporting on the race being held.

To investigate students' learning outcomes as a result of working on projects in the form of athletic competitions, lecturers evaluate them through two media: virtual learning and activity logs. Virtual learning is used to measure student learning outcomes in the knowledge domain, while the activity $\log$ is used to monitor student's activity in contributing to project implementation.

\section{FINDINGS AND DISCUSSION}

This research tries to describe the superiority of active learning implementation in learning for students in learning track and field. There are four findings that need to be discussed and discussed: virtual learning; personal account of activity log; event organizer; and assisting the school.

\section{A. Virtual Learning}

Virtual learning or vi-learn is a website domain which provides all teaching learning materials in track and field course. Virtual learning helps teachers to realize active learning with student-centered learning models [8]. Every pre-service physical education teacher is able to access and learn about track and field course by accessing the vi-learning website on www.vi-learn.unesa.ac.id anytime and anyplace. This digital resource does not only give benefit for the student, but also teacher. Teacher could identify student profile that appear on the website visitor as many as they use the website. Thus, it could detect the student activity and frequency on the utilizing the vi-learning.

Virtual learning will then become a medium in evaluating the knowledge of students to find out the learning results obtained. There are many measurement models available in virtual learning, but multiple-choice models are the easiest option to use in measuring student learning outcomes. Excellence in measuring the results of learning through virtual learning is that students can immediately know the results and the correct answer to the question being done. Thus, the measurement will be evaluative towards the student's knowledge.

\section{B. Personal Account of Activity Log}

Every pre-service physical education teachers have an account particularly to record their activities in officiating track and field championship. This account was functioned as personal reflection correlating with what activity that they have involved and what have they learn. By this activity log, they know what they need to learn in order to improve themself. 
Moreover, they could assess their own accomplishment during the class.

Activity $\log$ is a process-oriented assessment model of student learning outcomes as evidenced by the performance evidence in the form of products that can be produced by students during learning. Assessment of the activity $\log$ then uses a portfolio assessment model that can assess processoriented and product-oriented learning outcomes [9]. The portfolio becomes an appraisal model of student learning outcomes that is suitable for knowing the process of active student learning and being involved during the specified learning time span.

In addition, activity logs will assist lecturers in monitoring student learning activities. Activity logs can be viewed at any time by lecturers through lecturers' personal accounts integrated with personal accounts owned by students. Furthermore, the results of monitoring can be submitted to the students for further follow up. In this way, students are expected to be able to achieve the learning objectives that have been formulated in accordance with the expectations of the 2013 curriculum, namely: factual (terminology and discrete facts); conceptual (categories, theories, principles, and models); procedural (knowledge of a technique, process, or methodology); and metacognitive (including self-assessment ability and knowledge of various learning skills and techniques).

\section{Event Organizer}

Working together to run the track and field championship is an implication of their understanding about theory, knowledge and skill what they have learned. Furthermore, this officiating helps them to observe, interact, and participate directly with the school and participant. The participants of the officiating track and field championship are elementary, junior high and senior high school in east java province. So, by officiating this event, pre-service physical education teachers have a good chances to discuss and learn from physical education teacher from east java province. In additional, the participant of this event always increases constantly every year. In the $11^{\text {st }}$ track and field championship, there are 445 participants from 160 schools in east java participated in this event.

Being an event organizer in an athletic race is expected to present a real learning environment in learning the officiating athletic race. Where the committee will bring students as participants and teachers as official. With this kind of learning environment the requirements of active learning implementation can be achieved, that is students active to talk with other, listen, write, read, and reflect, and then apply what they have learned to real-life problems [10]. The demand for active learning is very likely to be fulfilled if the students really take advantage of environmental conditions that have been manipulated naturally through the race.

\section{Assisting the School}

There are volunteers who assist the school to participate in the track and field championship. They facilitate the school to apply and provide the important information about the track and field championship. Furthermore, the volunteer has responsibility to make sure that the school could participate well. Those volunteers are pre-service physical education teacher who are learning to be a physical education teacher as well. So by assisting the school, they were also asked to learn how manage and interact with the school and student. They were also asked to teach the student about the technique and rules of track and field. It is an appropriate time and place for them to use their knowledge and skill in to student or society.

Assisting the schools in the participation of track and field competitions is an assigned duty in learning. This task is expected to have an impact on students' interaction with school especially with PE teachers. Interaction between students and teachers is expected to provide experience to hone students' competence in collaborating with others.

\section{CONCLUSION}

Active learning model in track and field helps student to know the real application of track and field theory. Understanding the knowledge, mastering the skill, practicing teaching strategy, and simulating officiating of track and field were done performed in combination of class or laboratory with school or society. They are not only learning about the material, which was provided, but also from the problem or phenomena that they found in the real condition. It enriches their knowledge and capabilities as physical education teacher candidate of teaching track and field.

Active learning model helps pre-service physical education teacher understand deeper about track and field course. Because they learn from problem solving that they face in the real condition. So it is suggested to apply in the other course which is similar with track and field.

\section{REFERENCES}

[1] N. E. Adams, "Bloom's taxonomy of cognitive learning objectives," $J$. Med. Libr. Assoc., vol. 103, no. 3, pp. 152-153, 2015.

[2] L. P. Nelson and M. L. Crow, "Do Active-Learning Strategies Improve Students' Critical Thinking?," High. Educ. Stud., vol. 4, no. 2, pp. 7790, 2014.

[3] Suroto, "Inovation Teaching Method for Physical Education Teacher in Indonesia," in Proceeding 2nd International Conference of Sport Science, 2017, pp. 94-107.

[4] Ministry of National Education of Republic of Indonesia, Panduan Pembelajaran untuk Sekolah Menengah Pertama, 1st ed. Jakarta: Direktorat Jenderal Pendidikan Dasar dan Menengah, 2016.

[5] J. M. Kilgour, L. Grundy, and L. V. Monrouxe, "A Rapid Review of the Factors Affecting Healthcare Students' Satisfaction with SmallGroup, Active Learning Methods," Teach. Learn. Med., vol. 28, no. 1, pp. 15-25, 2016.

[6] C. Lonsdale, R. R. Rosenkranz, L. R. Peralta, A. Bennie, P. Fahey, and D. R. Lubans, "A systematic review and meta-analysis of interventions designed to increase moderate-to-vigorous physical activity in school physical education lessons," Prev. Med. (Baltim)., vol. 56, no. 2, pp. 
152-161, 2013.

[7] A. R. Mesquita et al., "The effect of active learning methodologies on the teaching of pharmaceutical care in a Brazilian pharmacy faculty," PLoS One, vol. 10, no. 5, pp. 1-16, 2015.

[8] G. F. Prassida and A. Muklason, "Virtual Class Sebagai Strategi Pembelajaran Untuk Peningkatan Kualitas Student-Centered Learning di Perguruan Tinggi," Teknologi, vol. 1, no. 2, pp. 95-98, 2011.

[9] Wahyudi, "Asesmen Pembelajaran Berbasis Portofolio di Sekolah," J.
Visi Ilmu Pendidik., vol. 2, no. 1, pp. 288-297, 2010.

[10] J. Neide, "Active-learning strategies for HPER," J. Phys. Educ Recreat. Danc., vol. 71, no. 5, p. 26, 2000. 